\title{
ПРОФЕСІЙНІСТЬ МЕДИЧНОЇ СЕСТРИ У СПІЛКУВАННІ 3 ПАЦІЄНТАМИ
}

\author{
А. В. Мединська, С. О. Коноваленко \\ Перший Київський медичний коледж \\ ДВНЗ «Тернопільський державний медичний університет \\ імені І. Я. Горбачевського МОЗ Украӥни»
}

У статті проаналізовано особливості вибору та використання комунікативної стратегії для ефективного спілкування медичної сестри з хворими. Дані дослідження сприяють глибшому й повнішому розумінню мовних прийомів, які використовують для різних соціальних груп населення та дають можливість медичній сестрі виробити певну точку зору на тимчасові й потенційні проблеми пацієнта.

\section{NURSE PROFESSIONALISM IN COMMUNICATION WITH PATIENTS}

\author{
A. V. Medynska, S. O. Konovalenko \\ First Kyiv Medical College \\ I. Horbachevsky Ternopil State Medical University
}

In this article there were analyzed the main peculiarities of the choice of communicative strategy for the effective interaction of the nurse and the patient. These studies provide rich material for a deeper and more complex understanding of linguistic techniques used for different social groups and enable the nurse to develop her own point of veiw on the temporary and potential problems of the patient.

Вступ. Важливою проблемою сьогодення $\epsilon$ здатність медичної сестри ефективно спілкуватися з пацієнтами. Задоволеність клієнта лікуванням та доглядом значною мірою залежить від того, чи було спілкування з медичним працівником позитивним, що прямо пропорційно залежить від якості взаємодій. Найчастіше пацієнти скаржаться на нездатність медпрацівників уважно їх вислухати, давати зрозумілі відповіді, насамперед, забезпечити належний догляд. Неефективне спілкування $є$ бар'єром на шляху до досягнення здоров'я. Взаємовідносини між медичною сестрою і пацієнтом - одна з важливих проблем медицини. Труднощі в комунікації медсестра-пацієнт впливають на якість допомоги і позначаються на перебігу лікувального процесу. Навіть стерті прояви конфліктних взаємовідносин, цілком відчутно впливають на настрій. У комунікації беруть участь обидві сторони.

Основна частина. У кожній ситуації спілкування використовується своя комунікативна стратегія. Стратегія спілкування реалізується в комунікативних тактиках, під якими розуміються мовні прийоми, що

(c) А. В. Мединська, С. О. Коноваленко, 2016 дозволяють досягти поставлених цілей в конкретній ситуації. При мовному впливі на різні соціальні групи населення потрібно також вибирати відповідні комунікативні тактики, маючи на увазі при цьому, що жодна з тих чи інших тактик не $є$ ефективною і універсальною. Необхідно підбирати таку форму вираження, яка була б переконлива тільки для того, кого переконуєш. Спілкування з пацієнтом у медичній сфері відбувається переважно у вигляді діалогу. Протягом розмови співрозмовники обговорюють скарги, тілесні відчуття, душевний стан, лікування, результат хвороби, іноді й діагноз. У рамках сформованої в сучасній медицині моделі співпраці діалог між медичною сестрою і пацієнтом передбачає і включає унікальність та рівність партнерів, відмінність і оригінальність точок зору, орієнтацію кожного на порозуміння та на активну інтерпретацію його точок зору партнером, очікування відповіді і його передбачення у власному висловлюванні, співвідношення яких і $\in$ метою діалогу.

Кожен із нас хоча 6 раз перебував у лікарні чи звертався в поліклініку, і враження по лікувальному закладі залежало не тільки від того, яке лікування 
було проведено, але і від того, як нас зустріли лікар і медсестра. В умовах лікувального закладу перший контакт пацієнта з медичним персоналом і, зокрема, з медсестрою має особливо принципове значення; саме він надалі визначає взаємовідносини з обох сторін, почуття довіри чи недовіри, приязні чи неприязні, наявність або відсутність партнерських відносин [1].

Спочатку розглянемо етапи встановлення відносин між медсестрою і хворим у період перебування його у лікувальній установі.

Розрізняють такі етапи:

а) початковий;

б) розгорнутий;

в) кінцевий.

На початковому етапі відбувається орієнтація, хворий і медсестра знайомляться один із одним. I хоча хворий захоплений власними проблемами, але в інтересах пристосування до нового середовища він змушений вступати в контакт з особами, які його оточують, брати до уваги місцеві звичаї, особливості. Медсестра і лікар у ході роботи отримують уявлення про поведінку хворого. Виникає зв'язок між ними і хворим. Пізнають вони і ставлення хворого до своєї хвороби. Дуже корисне вивчення і тих реакцій, які викликає хворий у лікаря, медсестри. Колишні враження, упередження, особисті спогади можуть бути спроектовані на нового хворого, можуть послужити таким чином причиною помилок. Дуже цікаві спогади медсестри і лікаря, пов'язані з лікарняним ліжком (i, звичайно те, що побували на ньому хворі). «На цьому ліжку лежав...». - Це почуття викликає враження повторюваності. Сліди спогадів про колишніх хворих проектуються знову на пацієнта, покладеного на те ж місце в палаті. На початковому етапі хворому можуть заважати забобони, упередження, спогади, які він проектує на персонал: на лікарів і медсестер.

На розгорнутому етапі лікар і пацієнт познайомилися один із одним. Подальша робота вже залежить від сформованого контакту між ними. Змінюється картина хвороби, все, що відбувається з хворим, може викликати появу страху, невпевненості, іронію, гірку насмішкуватість, прискіпливість. Все це можна зменшити або взагалі усунути, проявляючи увагу до хворого, розмовляючи з ним, вислуховуючи його.

На кінцевому етапі труднощі зазвичай виникають при виписуванні з лікарні. Хворий стурбований, він боїться залишити стіни, де був надійно захищений від небезпеки. Не раз доводиться чути: «Хворий не хоче виписуватися ...». Хворого в таких випадках мучать сумніви: «Що буде зі мною вдома?», «як зможу я дотримуватися дієти?», «Що буде, якщо ...?» та ін. Хворий повинен бути відповідним чином підготовлений до виписування. Неодноразові заняття, бесіди про все те, що турбує його, що викликає побоювання і страхи у зв'язку з виписуванням, все це сприяє усуненню тих труднощів, які часто пов'язані з виписуванням хворих із лікарні [2, 3].

Особистість медичної сестри, метод ії роботи, стиль, поведінка, володіння технікою психологічної роботи з хворими - все це, як і у випадку лікаря, - саме по собі може слугувати ліками, сприяти зціленню.

Медсестрі доводиться виконувати керівну, виховну й освітню діяльність. Прийом хворого в лікувальній установі, його знайомство з розпорядком життя лікарні, повідомлення йому необхідних під час його перебування тут відомостей, виконання призначень лікаря, - все це виконується через медсестру, з ії допомогою. Лікар не має можливості по кілька разів пояснювати хворому одне і те ж. Його представником, його «послом» серед хворих $\epsilon$ медсестра, вона і «перекладає» хворим все, що було ними неправильно зрозуміле, взагалі не зрозуміле або не так сприйнято, як це потрібно було б. Дуже важливим $\in$ вміння медсестри бачити, що і як зрозумів хворий, у чому полягає непорозуміння, здатність вміло роз'яснити йому незрозуміле чи погано зрозуміле.

Хворий дуже багато чого може дізнатися про неправильність свого способу життя, сама хвороба вимагає від нього по-новому поводити себе, пристосуватися до нових умов. Медсестра, сприяючи здійсненню на практиці цього нового, здорового способу життя, фізичної та психічної гігієни, допомагає хворому розвиватися. Ії робота може бути ефективна тільки в тому випадку, якщо вона добре знає своїх хворих. Адже необхідно знати, кому, що і як потрібно пояснювати. ІІї погляди і думки повинні відповідати тому загальному духу, який панує у відділенні. Помилки її, недоліки особистості, сутички з колегами і хворими дуже заважають роботі.

Все в медсестрі повинно прихиляти до себе пацієнта, починаючи з їі зовнішнього вигляду (підтягнутість, акуратність, зачіска, вираз обличчя). Абсолютно неприйнятне звертання «хворий», наче пацієнт втратив право на ім'я та по батькові. Щоб між медсестрою і пацієнтом склалися партнерські стосунки, пацієнт повинен відчувати, що ви хочете йому допомогти. Тільки тоді виникає той довірливий діалог, під час якого медсестра дізнається необхідні їй відомості про пацієнта, 
особливості його життя, його думку про захворювання, про надії на одужання, плани на майбутнє. Під час таких бесід виявляються ставлення пацієнта до родичів, роботи, інші проблеми, а всі ці відомості дають медсестрі можливість встановити свій сестринський діагноз.

Медсестра постійно повинна пам'ятати, що партнерські стосунки з хворими не повинні переходити в панібратські: провідна роль завжди залишається за нею. Вона співчуває хворому, між ними встановлюється так звана емпатія, тобто медсестра здатна пізнати суть і глибину переживань і страждань пацієнта, але вона не ідентифікує себе з його переживаннями. Пацієнт завжди повинен бути впевнений, що їх розмови мають конфіденційний характер. Знаючи особливості переживань хворого, медсестра тактовно пояснює пацієнту не тільки його права, але й обов'язки, розповідає в доступній для хворого формі про необхідні обстеження, підготовку до них, про майбутнє лікування.

Відмова пацієнта від того чи іншого виду обстеження або лікування не повинна викликати до нього негативного ставлення з боку медичного персоналу.

Обов'язок медсестри - бути чесною і правдивою до пацієнта, але розмови про діагноз, особливості захворювання не можуть виходити за межі, позначені лікуючим лікарем. Це відноситься і до бесід медсестри з родичами пацієнтів.

Погляди лікаря і медсестри на якість та особливості догляду за хворим можуть не збігтися. Тоді потрібно дуже тактовно обговорити конфліктні питання з лікарем, i, якщо досягли згоди, це полегшить роботу. обговорювати ж такі ситуації з іншими особами або відразу звертатися зі скаргами до керівництва не варто - це може призвести до взаємних образ, небажаних ситуацій у колективі. Право відстоювати свою точку зору необхідно поєднувати з високою вимогливістю до себе, здатністю визнавати і виправляти свої помилки, виявлені самостійно або колегами.

Гуманізм професії створює основу для захисту особистої гідності медсестри, її фізичної недоторканності, права на допомогу при виконанні професійних обов'язків. До речі, і її життєвий рівень повинен відповідати статусу її професії.

Мистецтво сестринської справи полягає в гармонійному поєднанні творчого підходу та науковому обґрунтуванні процедур, посібників, словесних впливів і бесід у процесі догляду за хворим; в умінні захистити пацієнта від хвилюючих його негативних думок і почуттів, які суттєво затягують одужання. Такий захист важливий для людей будь-якого віку, але особ- ливо для дітей та літніх людей. щоб здійснити його, медсестра повинна бути готова до співпереживання, проявляти доброту та чуйність. Але в ряді випадків просто хороших людських якостей не достатньо. Щоб застосовувати їх професійно, з високим ступенем надійності, треба засвоїти певні елементи медичної психології та психотерапії.

Пацієнти старечого віку потребують особливої уваги. Такі вікові психічні зміни, як зниження пам'яті, уваги, погіршення процесів пристосування психіки до нових умов, емоційна лабільність, психологічні проблеми (наприклад, пов'язані з перенесеними втратами, почуттям самотності, з «конфліктом поколінь») роблять дану вікову групу особливо уразливу для негативних психологічних впливів.

Пацієнт, який потребує сестринського догляду і отримує його, - це насамперед людина, особистість, що характеризується певними особливостями. Психологічно комфортний клімат має найпотужніший лікувальний вплив - про це треба пам'ятати і медсестрам, і молодшому медичному персоналу, і медичним реєстраторам, тому що, як і театр, поліклініка починається з вішалки.

Передача інформації в процесі спілкування здійснюється як за допомогою слів, тобто вербально, так і без слів, невербально - за допомогою жестів, міміки, ходи, пози, інтонації і т. д. Для практичної діяльності медсестри характерна своя специфіка вербального спілкування.

Під простотою спілкування розуміють стислість, закінченість фраз, які містять зрозумілі слова. Медсестрі необхідно пам'ятати, що хворій людині буває складно оцінити суть багатослівного повідомлення і побудувати на його основі тактику своїх подальших дій. 3 іншого боку, стисла інформація може вимагати їі неодноразового повторення або уточнення, оскільки при цьому розуміння може бути неповним. 3 особливою обережністю потрібно підходити до використання в спілкуванні з пацієнтом абревіатур. При першій зустрічі з пацієнтом спеціальні терміни краще вимовляти повністю, і тільки в подальшому, коли у медсестри вже з'явиться впевненість у тому, що прийняті скорочення однозначно розуміються хворим, можна почати їх використовувати.

Критерій ясності інформації передбачає, що після отримання повідомлення пацієнт може однозначно відповісти на питання «що, як, скільки, де, коли, чому», що стосуються його подальших дій (чи буде він діяти відповідно до своїх відповідей - інше питання). 
Використання слів: «більше», «менше», «частіше», «рідше», «іноді», «мало», «багато», «вранці», «завтра», «чекайте» і т. д. може сприяти неоднозначній інтерпретації повідомлення. Буває, що повідомлення залишається незрозумілим і у разі якісної розбіжності вербального і невербального способів спілкування.

Kozier B. i Erb G. називають критерій «заслуговує на довіру» найважливішим для ефективного спілкування і вважають, що на довіру пацієнта до медсестри впливають: ставлення до неї інших медичних працівників; знання медсестрою предмета обговорення i, одночасно, розуміння нею обмеженості своїх знань та вміння зізнатися в цьому; дотримання конфіденційності стосунків.

Автори відзначають, що повідомлення, зроблене впевненим і рішучим тоном, швидше викличе довіру в пацієнта, ніж передана з нотками невпевненість у голосі. У той же час вони застерігають від самовпевнених, авторитарних суджень, вважаючи більш прийнятним конструктивний діалог. Проблеми, які виникають у взаємовідносинах між лікарями та медсестрами свідчать про несформованість навичок ефективного спілкування, що, у свою чергу, накладає відбиток на ставлення пацієнтів до медсестер і до системи охорони здоров'я в цілому [4].

Пацієнт не завжди може дізнатися ставлення медсестри до якого-небудь питання, хоча «вона зобов'язана поважати право пацієнта на отримання інформації про стан його здоров'я, «моральний обов'язок медсестри інформувати пацієнта про його права ...». Щоправда, з іншого боку, «функції інформування пацієнта та його близьких належать лікарю». Як показує досвід взаємодії з практикуючими медсестрами, вони не готові звести цю частину своєї діяльності до належної. Усе це, з нашої точки зору, не сприяє формуванню довірливих стосунків між пацієнтом і медсестрою.

Критерій «доречність повідомлення», «вдалий вибір часу» можна об'єднати в один - «доречність». У лПЗ пацієнт перебуває в стані перманентного очікування лікарського обходу, запрошення на маніпуляції, діагностичні процедури, обід і т. д., він щасливий, що на «нього звернули увагу». Знаючи це, медсестра може втратити відчуття міри - наприклад, допомагати виконувати гігієнічні процедури, робити клізму або проводити катетеризацію, подавати судно або сечоприймач у присутності сусідів по палаті або навіть відвідувачів.

Облік індивідуальних особливостей пацієнта в цілому ї̈х змін під час перебування в ЛПЗ ми вважаємо найважливішим критерієм вербальної адекватності передачі інформації. Саме цей критерій $є$ мірою простоти ясності, доречності, ступеня довіри відносин для конкретного пацієнта.

До вербальних навичок спілкування, якими має володіти медсестра, можна віднести мистецтво слухати. Уміння слухати на відміну від здатності просто чути передбачає наявність певної дисципліни, вимагає певних зусиль. При бажанні це вміння можна придбати, «хоча воно є одним з найбільш важких аспектів акту спілкування».

Психологи виділяють активне, пасивне і емфатичне слухання. Під активним вони розуміють слухання, при якому на перший план виступає відображення інформації, а під емфатичним - відображення почуттів. Ми вважаємо таке «препарування» дуже доречним для сестринської практики і надалі будемо дотримуватися цього тлумачення понять.

Медсестрам у силу специфіки їх професії доводиться взаємодіяти з людьми, які перебувають в стані сильного емоційного збудження. У цьому випадкуприйоми активного слухання не спрацьовують. Ваш співрозмовник не $\in$ в повному сенсі цього слова співрозмовником, оскільки вже не контролює власні емоції, не здатний вловлювати зміст розмови, та він і не намагається це робити. Йому треба тільки одне - заспокоїтися, налагодити самоконтроль; тільки тоді він буде чути те, що ви йому говорите. У таких випадках ефективне пасивне слухання. Медсестрі насамперед потрібно оволодіти навичками пасивного слухання. В іншому випадку вона до кінця чергування навряд чи зможе контролювати власні емоції, а посади психолога-консультанта по роботі з середнім медичним персоналом у наших лпз немає.

Для пацієнта дуже важливо, щоб медична сестра зрозуміла й розділила його почуття. Саме це дає йому відчуття полегшення. Тому, коли медсестра проводить бесіди з пацієнтом, характер яких в ідеалі повинен бути терапевтичним (наприклад, при підготовці до операції, до якої-небудь процедури, прийняття важливого рішення), для неї насамперед повинна бути важлива не стільки інформація, яку пацієнт повідомляє, скільки почуття, які він переживає із цього приводу. Ось чому медсестрі так необхідний навик емфатичного слухання, тобто такого, при якому вона здатна якоюсь мірою відчувати ті ж почуття, що і пацієнт, i, подібно до дзеркала, відображати їх, щоб він почав краще розуміти себе.

Уявити собі емоційне життя пацієнта може медсестра, яка володіє розвиненою здатністю до пере- 
живання і співпереживання, тобто має досить високий рівень емпатії - розуміння емоційного стану іншої людини, співпереживання, проникнення в його суб'єктивний світ. Необхідно розрізняти жалість («мені шкода вас»), симпатію («я співчуваю вам») і емпатію («я - з вами»).

«Оцінка емпатії виявилася тісно пов'язаною 3 такими характеристиками лікаря, як професійне мистецтво, теплота, доброзичливість, надійність, досвідченість, сила, щирість та ін.». Отже, терапевтичний ефект залежить від того, якою мірою пацієнт відчуває себе об'єктом турботи, чуйності та розуміння, тобто від емпатичного зв'язку з медичним працівником $[5,6]$.

Багато авторів вважають емпатію генетично детермінованою властивістю, посиленою або ослабленою життєвим досвідом індивіда. Існують різні тренінгові методи, що підвищують здатність до емпатії і вміння більш ефективно застосовувати їі в спілкуванні з пацієнтом. В умовах дефіциту часу необхідно розвивати «професійну емпатію», що дозволяє медсестрі на основі «читання» експресивних елементів поведінки пацієнта проникати в його емоційний стан, а потім усім своїм виглядом і висловлюваннями показувати йому, що його почуття зрозумілі.

Традиційне спілкування передбачає взаємозв'язок трьох його сторін: комунікативної, інтерактивної і перцептивної, що в реальній дійсності не реалізуються ізольовано. Комунікативна функція спілкування полягає в обміні інформацією, у даному випадку між медсестрою і пацієнтом, інтерактивна полягає в організації взаємодії між комунікаторами, перцептивна (від лат. perceptio - сприйняття) - у спілкуванні як процесі сприйняття партнерами одне одного та встановлення певного рівня взаєморозуміння.

Мета медсестри - виробити певну точку зору на тимчасові й потенційні проблеми пацієнта.

Комунікативній стороні спілкування властива наявність:

- зворотного зв'язку;

- комунікативних бар'єрів;

- комунікативного впливу;

- вербального і невербального рівнів передачі інформації.

У контексті спілкування медсестри і пацієнта зворотний зв'язок - це реакція пацієнта на поведінку медсестри. Зворотний зв'язок покликаний допомогти медсестрі зрозуміти, як вона сама, її поведінка та інформація, подана нею, сприймаються і оцінюються пацієнтом.
Під час діалогу медсестра і пацієнт постійно міняються комунікативними ролями «розмовника» $\mathrm{i}$ «слухача». Тому медсестра також висловлює свою реакцію - прямо або побічно. У першому випадку інформація, що надходить від медсестри («розмовника»), у відкритій формі містить реакцію на поведінку пацієнта («слухача»): «Я не зможу відповісти на ваше запитання», «Я не вітаю порушення Вами режиму», «Я важко розумію, про що зараз йде мова» і т. д.; реакція може проявлятися жестами та іншими елементами невербальної комунікації. Такий зворотний зв'язок забезпечує адекватне розуміння її пацієнтом і створює умови для ефективного спілкування.

Непрямий зворотний зв'язок - це завуальована форма передачі партнеру інформації. Для цього використовуються риторичні запитання: «Ви дійсно так вважаєте?», «l це допоможе?». Іронічні зауваження: «Так ... У нас тепер всі знають, як треба лікувати», вербальні та невербальні реакції і т. д. У даному випадку «слухач» повинен сам здогадуватися, що саме хотів сказати йому «розмовник», і яка насправді його реакція і ставлення. Природно, здогадки не завжди виявляються вірними, що значно ускладнює процес спілкування.

Виступаючи в ролі «слухача», медсестра повинна по можливості неоднозначно реагувати на слова і поведінку пацієнта. У скрутних випадках краще сказати: «Це не входить в мою компетенцію, потрібно порадитися з лікарем, старшою медсестрою». Якщо пацієнт надає медсестрі інформацію, яка не піддається однозначному тлумаченню, вона зобов'язана поставити уточнювальні питання.

Відомо, що спонтанний прийом сигналів зворотного зв'язку неповний і інтерпретується через власну систему координат. Ми вважаємо, що система координат медсестри детермінується ії професійною роллю і ґрунтується в більшості випадків на позитивному ставленні до пацієнта.

3 іншого боку, торкаючись феномену зворотного зв'язку, не можна не помітити, що подібна поведінка пацієнта, можливо, є відповіддю на поведінку медсестри, яка дозволила йому поводити себе подібним чином. У процесі спілкування постає проблема не стільки обміну інформацією, скільки її адекватного розуміння. Від чого вона залежить?

По-перше, форма і зміст повідомлення істотно пов'язані з особистими особливостями «розмовника», його уявленнями про «слухача» і ставленням до нього і до ситуації, в якій відбувається спілкування. По-друге, 
усіляке повідомлення трансформується під впливом особливостей особистості «слухача», його ставлення до автора повідомлення, тексту, ситуації. Так, одні й ті ж слова, почуті пацієнтом із вуст лікаря, медсестри, сусіда по палаті, родича, можуть викликати у нього різні реакції. Зауваження лікаря, швидше за все, буде вислухано з належною увагою, а зауваження сусіда з роздратуванням. Одну й ту ж інформацію різні люди можуть сприймати зовсім по-різному залежно від виховання, особливостей особистості й навіть політичних пристрастей. Одне і те ж висловлювання медсестри один пацієнт сприйме як справедливе зауваження, а інший - як «вічну причіпку».

Адекватне сприйняття інформації залежить також від наявності або відсутності в процесі спілкування комунікативних бар'єрів. У даному випадку можна говорити як про існування у пацієнтів психологічного захисту від інформації про стан здоров'я і про подальші прогнози, так і про можливі перешкоди на шляху адекватного сприйняття інформації медсестрою. Автори виділяють такі бар'єри: фонетичний, семантичний, стилістичний, логічний, соціально-культурний та бар'єри відносин.

Фонетичний бар'єр може виникати, коли медсестра і пацієнт говорять швидко й невиразно або на різних мовах і діалектах, мають дефекти мови та дикції.

Семантичний (змістовий) бар'єр пов'язаний з проблемою жаргонів, властивих людям певних вікових груп, професій або соціального стану (наприклад, мова підлітків, наркоманів, моряків, жителів віддалених місцевостей і т. д.). Зняття такого бар'єра - актуальна проблема для представників медичної професії, оскільки від його подолання залежить успішність терапевтичного контакту. Тому в медсестри повинні бути навички засвоєння чужих семантичних систем. Особливо це важливо, на наш погляд, для організації ефективного спілкування з підлітками. 3 іншого боку, буває, що медпрацівник сам провокує виникнення змістового бар'єра в пацієнта, без потреби використовуючи професійні терміни. Надалі це може призвести до розвитку патологічних реакцій внаслідок несприятливого сестринського впливу на психіку пацієнта.

Виникнення стилістичного бар'єра є можливим при невідповідності мови медсестри ситуації спілкування, наприклад, при ії фамільярній поведінці, коли вона всіх пацієнтів старших певного віку називає «бабуля» і «дідусь», не враховує психологічних особливостей людей та їх психологічного стану (зміна свідомості внаслідок захворювання або приймання лікарських препаратів).
Коли медсестра проводить психопрофілактичні бесіди з пацієнтами перед будь-якими операційними втручаннями, навчає їх способам приймання лікарських препаратів, використанню апаратури, знайомить з різними методиками здорового способу життя, може виникнути бар'єр логічного нерозуміння, тобто логіка міркувань медсестри може бути або занадто складна для пацієнта, або здаватися йому невірною або непереконливою. Логіка доказів пацієнта також може бути помилковою з точки зору медичної сестри.

Причиною виникнення соціально-культурних бар'єрів може виступати сприйняття пацієнта як особи певної професії, національності, статі, віку, соціального статусу. Медсестра повинна бути готова до виникнення цього бар'єра, тому що для певної частини хворих ії авторитет недостатній; особливо це актуально для молодих медсестер.

У процесі спілкування медсестри і пацієнта можуть виникати і бар'єри стосунків. Мова йде про негативні емоції, які викликає людина. Причину цього часто важко усвідомити.

Розглядаючи сутність психологічного бар'єра, не можна не помітити, що будь-який з них - це насамперед захист, який вибудовує пацієнт на шляху запропонованої йому інформації. Наприклад, уявімо собі завзятого курця, який почував себе погано і звернувся за порадою до свого товариша-лікаря, який оцінив стан його здоров'я і стверджує про необхідність кинути курити, наводячи такий аргумент: «У тебе стає жорстким дихання, і серце не те» [7].

Якщо людина не хоче витрачати зусилля і розлучатися зі стійкою звичкою, як вона може захиститися від настільки неприємної інформації? Є декілька психологічних бар'єрів, які використовуються з цією метою. Перший шлях - тактовне спотворення такої інформації: «Сьогодні я почував себе значно краще, серце спокійне - це було тимчасове явище» або: «У цій замітці йдеться про те, що куріння допомагає впоратися зі стресом». Другий шлях - зниження авторитетності джерела інформації: «Звичайно, він лікар, але вже багато років як займається гастроентерологією. Багато він розуміє в серцевих хворобах!». Нарешті, третя можливість - захист через нерозуміння: «Знав би він, що таке дійсно погане дихання! Ось у мого сусіда, наприклад! I нічого, курить».

Будь-яка інформація, яка надходить до «слухача», несе в собі той чи інший елемент впливу на його поведінку, думки, установки з метою їх часткових або повних змін. 
Висновки. Дані дослідження сприяють глибшому й повнішому розумінню мовних прийомів, які використовують для різних соціальних груп населення та дають можливість медичній сестрі виробити певну точку зору на тимчасові й потенційні проблеми пацієнта.

\section{ЛITEPATУРA}

1. Елементи психотерапії в загальносоматичній поліклініці / Ю. П. Бойко [та ін.]. // Медична сестра. - 2000. - № 2.

2. Культура фахового мовлення : навч. посіб. / [за ред. Н. Д. Бабич]. - Чернівці : Книги - XXI, 2006. - 496 с.

3. Островська І. В. Медсестра і пацієнт: спілкування для обміну корисною інформацією / І. В. Островська // Медична сестра. - 2000. - № 4.

4. Островська І. В. Вербальний спосіб спілкування / І. В. Островська // Медична сестра. - 2001. - № 7.
Всі вищевикладені завдання можуть бути виконані медсестрою в наш час лише при постійному вдосконаленні нею своїх знань і навичок. Крім вивчення тієї галузі, в якій вона працює, медичній сестрі необхідно постійно займатися підвищенням свого культурного рівня та вдосконаленням особистості.

5. Шкуренко Д. А. Спільна й медична психологія / Д. А. Шкуренко. - Ростов-на-Дону : «Фенікс», 2002. - 352 с. 6. Косенко В. Г. Медицинская психология для медсестер и фельдшеров / В. Г. Косенко, Л. Ф. Смоленко, Т. А. Чебуракова // Серия «Медицина для всех». - Ростов-на-Дону : «Фенікс», 2002. - 416 с.

7. Психологія: навч. посіб. / О. В. Винославська, О. А. Бреусенко-Кузнєцов, В. Л. Зливков [та ін.] ; за наук. ред. О. В. Винославської. - К. : Фірма «ІНКОС», 2005. - 352 с. 